\title{
Martial Law and the State of Siege
}

\section{Max Radin*}

THERE is a strong tendency in time of war for many sober citizens to demand a severer, harsher, more drastic and more expeditious enforcement of all types of police regulations than they would endure in time of peace. This is psychologically thoroughly intelligible and the need for greater effectiveness is to a large extent urgent and imperative. But the tendency can easily get out of hand, especially since those charged with enforcement are always-in peace as well as in war-inclined to be impatient of the restraints which orderly legal procedure has placed upon the free exercise of their vitally important and indispensable powers. In war time the commendable eagerness of all citizens to strike a blow for their country can readily translate itself into an impulse to strike a blow anyhow without too cautious an examination of whether it will in fact benefit the country.

. In war time, we are often told, we leave the rule of law and are governed by necessity which by overwhelming popular agreement, expressed in proverbs and current speech, "knows no law". Those who like to fortify their convictions by Latin tags may add the famous phrase silent leges inter arma, ${ }^{2}$ which Cicero used merely in connection with the right of personal self-defense.

That, when war is declared or is imminent, we must at once cast aside all forms of law and gladly submit to personal and irresponsible rule by military or police officials, is strange doctrine for pro-

*Professor of Law, University of California; A.B., College of the City of New York; LL.B., New York University; Ph.D., Columbia University. Author of The Lreisration of the Greets and Romans on Corporations (1909); Handbook of Roman Law (1927) ; Trual of Jesus of Nazareth (1928); The Lawful Pursutt of Gatn (1931); Handbook of ANgio-American Legal History (1936); THe Law and Mr. SMitu (1938); Manners and Morals of Business (1939); Law as Logic and Expernence (1940); a chapter in MY PHuosopHy of LAw (1941); and of numerous articles in various legal periodicals.

1 The plurase necessitas non liabet legem seems to have been first used by St. Augustine, Solil. An. c. 2. It has become one of the commonest of proverbial expressions. In the debate on the Ceylon investigation, Gladstone used the words, ". . . does not it seen to follow that what he [the military commander] has done has not been done under the law so to be called, but under a necessity which is above the law?" Sel. Com. on Ceylon, 2d Rep. 12 Parl. Papers (1850) qu. 5477, cited from Falraran, Tye Law gr Martiar Rule (1930) 49.

2 CrCERo, Pro MIIONE, \$10. The very next sentence indicates that so far from being silent, the laws rather volubly asserted the right of self-defense. 
fessed democrats to maintain. Yet it has been maintained in England and the United States, and above all has been presented as the doctrine of fearless realists who face facts as against theoreticians who nurse fond illusions. ${ }^{3}$ Unfortunately the Anglo-American tradition on this matter is confused and contradictory. ${ }^{*}$ For the most part, the drastic gentlemen have had their way and the majority of persons who have expressed themselves on the subject have declared frequently and emphatically that the law needed for war conditions is martial law, that is to say something which is properly not law at all, but a denial of law. ${ }^{5}$

It has seemed to me proper to examine briefly the experience of another people that consciously based its principles of freedom and democracy on the model of England and America and until the great betrayal of 1940 developed them as fully as any other country had done. ${ }^{6}$ The French political systems that followed the Revolution show no unbroken growth of freedom and democracy, and each in turn, the Third Republic as well as the Empire that preceded it, or the bourgeois monarchy that preceded the Empire, had weaknesses and vices in abundance. It may be that in this respect France was not unique among the nations of the world.

3 There is a distinct tone of impatience on the part of those who discuss martial law. This tone is certainly in part due to social and political prepossessions in favor of drastic suppression of any type of opposition to authority. The violent defense of Governor Eyre in Jamaica by such a pre-Fascist Fascist as Carlyle and the frantic defense of Amritsar by the Morning Post and its fellows, are striking examples that the matter is not always dealt with by rational arguments.

* Two excellent books, both of fairly recent date, give the development of martial law in England and the Urited States in considerable detail and subject it to a keen and object scrutiny. They are FaIRMan, op. cit. supra note 1, and RANKIN, WHEN CIVII LAw FaIs (1939). The literature on the subject, especially in legal periodicals, is well given in the notes to both books, espccially in the bibliography of Mr. Rankin's book, ibid. at 206. Even this is merely a selection. Much of what is discussed in America under martial law is given for England in 2 Clode, The Mnurtary Forces of the Crown (1869), which as its name indicates is properly concerned with military law.

5 The opinion of Sir Matthew Hale is often quoted to the effect that martial law is not law, but something indulged rather than allowed as law. HALE, History of THE Cosrmon Law (1820) 34. Cf. In re Egan (C. C.N.D.N. Y. 1866) 8 Fed. Cas. No. 4303. "Martial law is regulated by no known or established system or code of laws, as it is over and above all of them." Ibid. at 367. It is to be noted that despite these words, Justice Nelson found that the conviction of the prisoner was illegal.

C Obviously what type of law is now in operation in occupied France would defy ordinary canons of legal examination. Even in so-called unoccupied France, the shadow of the grim master vitiates any effort to apply a system that guarantees civil rights. In what follows, I shall speak of French law as it was before the capitulation, and speak of its provisions as though they were now in force. 
What is expressed in English as martial law has as its counterpart in France, the état de siege, which we may refer to by its literal rendering "state of siege", although neither in French nor in English is it confined to placés under siege. ${ }^{7}$ It ineans the situation of places, large or small, invested or overrun or threatened by armed enemies or endangered by insurrection. That is of course the situation under which in common law countries martial law has been declared necessary, and under which the common law has been suspended. How did the French system deal with the problem?

Perhaps it is necessary at the outset to purge our common law minds of current miscónceptions about the French criminal law in general. So far from proceeding on a "presumption of guilt", the presumption of innocence was a forinal part of the French constitution, and was enforced at least as consistently as it is in England or America. Again, ex post facto laws were prohibited, as well as double jeopardy. One might add, that differently from the common law, the accused always had the not unsubstantial advantage of being the last to address the jury: ${ }^{8}$

We ought further to add that the common confusion between military law and martial law, so frequent in coinmon law discussion, was rarely made in France. 9 France had a brief and compact "Code of Military Justice" of which one book dealt with peace conditions and the other with war. ${ }^{10}$ This Code is a far better and more workmanlike

\footnotetext{
${ }^{7}$ It always applied to sections actually occupied by an invading army as well as besieged cities.

8 Since, as we shall see, the law of the state of siege adopts for some purposes both the penal and the civil code, it is necessary to have these facts in mind. The absurd statement that there is no presumption of innocence in French law is in direct contradiction with the words of the French Bills of Rights, art. I, \$9. It may be said that the "positive school" of Italian criminology repudiates the presumption. Cf. FERRI, PrINCIPII DI Diritio Crimtarale (1928) 430 , who does favor in special circumstances a presunzione di dolo. But even they apply the long established rule of the Roman law that the prosecution bas the burden of proof. Cf. the maxims, In dubio pro reo and actore non probante absolvitur rens, derived from such passages as Ulpian, D. 22.3.18.2 and Gaius, D. 50.17.56.125, and Paulus, D. 50.17.56.155. Cf. for the history of the maxim, Moser, IN Dubro Pro Reo, Thesis (Murich, 1933).

${ }^{9}$ This confusion may have arisen from identifying the term "marshal", meaning the law applied in the Marshal's Court, with the word "martial". The original Marshall had nothing whatever to do with the god of war. Cf. FAIRMAN, op. cit. stupra note 1, at 39 et seq. The distinction is made in such cases as Jolunson v. Jones (1867) 44 Ill. 142; Bishop v. Vandercook (1924) 228 Mich. 299, 200 N. W. 278; State v. Rankin (1867) 44 Tenn. 145; and most fully in In re Kalanianaole (1895) 10 Hawaii 29. ScHnLER, Mititary Law and Defense Legislation (1941), is specifically devoted to military law as contrasted with martial law.

10 Code de Justice Muttare Pour L'Aradie de TERRe, as finally formulated by a law of March 9, 1928, see Code PéNac (1938).
} 
piece of legislation than our Articles of War or Manual for CourtsMartial.1I The Code deals with the organization, powers and functions of military tribunals which in time of peace have jurisdiction, only and exclusively, over soldiers, and in time of war, over soldiers, enemies and spies and over citizens who are accomplices or accessories in cases of offenses by soldiers.

In a state of siege, military tribunals displace in whole or in part civil tribunals. But they are not necessarily the tribunals defined and described in the Code of Military Justice. They may be variously and specially constituted according to the needs of the time and place, and they have jurisdiction over the entire population, soldiers and civilians alike.

But the vital point is that the state of siege is not a condition in which law is temporarily abrogated, and the arbitrary fiat of a "commander" takes its place. ${ }^{12}$ It is eniphatically a legal institution, expressly authorized by the constitutions and the various bills of rights that succeeded each other in France, and organized under this authority by a specific statute.

That this is so is definitely and firmly maintained by almost all authorities, doctrinal and official alike. It is stated emphatically by such men as Hauriou, ${ }^{13}$ Esmein $^{14}$ and Duguit ${ }^{15}$ who represent three very different attitudes to authoritarian principles of law. And it appears affirmatively from the history of the state of siege. ${ }^{16}$

1141 StaT. (1920) 787, 10 U.S. C. (1940) c. 36; In re Brodie (C. C. A. 8th, 1904) 128 Fed. 665 ; SchIller, op. cit. supra note 9, at 371. The MaNual for Courts-MrartIaL (1927), is issued by the War Department. Cf. also Hoover, Army Courts-Martial in Legal Essays IN TRIBUTe to ORRIN KIP MCMURRAY (1935) 165. For sharp criticism of the Articles of War, see articles cited in SCHILLER, op. cit. supra note 9, at 358, n. 3, especially Ansell, Military Justice (1919) 5 CoRN. L. Q. 1.

12 The statement that martial law is the "will of the commander" is attributed to the Duke of Wellington, 115 Hansard Parl. Debates (3d Series, 1851) 880, quoted by Falearan, op. cit. supra note 1, at 4, n. 4. It appears specifically in American cases: Diekelman v. United States (1875) $11 \mathrm{Ct}$. Cl. 417, 439; In re Egan, supra note 5, at 367; Johnson v. Jones, supra note 9, at 153.

13 Haurjou, PrÉcas Ex. de Drort Constitutionnel (4th ed. 1938) 158-161. It is a highly commendable fact in French legal literature that an elementary manual is frequently, as in this case, the work of one of the greatest of French jurists. The matter is more fully treated in 1 HaURIoU, DroIt ADMOMISIRATIF (12th ed. 1929) 127 et seq.

14 1 Esmein, Eléatents de Droit Constitutionner Françats ex Comparé (8th ed. 1928) 30, n. 84.

16 2 Duguit, Traité de Drort Const. (2d ed. 1924) 338-339.

16 This is most completely set out in 5 ibid. at 74-75. A number of special studies of the state of siege in France are frequently cited, chiefiy Rosenr, L'ETAT DE STÈGE Poumtiqux, Thèse (Toulouse, 1918); others not available to me are Correx, L'Orgar- 
It begins with the Revolution itself. One of the first laws of the Constituent Assembly was to provide for the declaration of a state of siege. ${ }^{17}$ This was the "real" state of siege, applying to actual war conditions. In practice this was extended beyond places which were the scene of hostilities and in 1848, the Constitutional Assembly of the Second Republic made constitutional the "état de siege fictif", which may be translated as the "constructive state of siege". It was provided, "A law will set forth the situations in which a state of siege may be declared. This law will regulate the procedure and effects of such a measure." 18 The first law dealing with it was the law of August 9,1849 , still in force at the destruction of the Third Republic.

The terms of the constitutional provision seem to indicate that only the legislature could declare a constructive state of siege. But in fact, it was often done by decree. The Constitution of $1852^{10}$ gave the head of the state (the President, then the Emperor) the right to declare a state of siege but required confirmation by the senate. However, an executive decree was used for that purpose on May 16, 1877. With explicit reference to this improper procedure, a law of the following year provided that only the legislature could declare it, if it was in session, and only for a specified period, after which it would automatically cease. ${ }^{20}$

Nonetheless, a governmental decree of August 2, 1914, declared a state of siege for all France. This was necessitated by the outbreak of World War I. The chambers were not then in session. When they assembled a law confirmed the declaration for the duration of the war, but provided that the state of siege might be partially and temporarily raised by the government.

The state of siege lasted till October 12, 1919, but the government on September 3, 1915, remvested the civil authorities with full powers in sections not directly within military zones. This was under the express provision of the law of $1849 .^{21}$

That law had several important provisions. By article 7 it was provided, "As soon as the state of siege is declared, all the powers

zzation de L'śttat de Stìge, Thèse (Dijon, 1916); Reinach, L'Etat de Stìge, These (Paris, 1885), and articles by Barthélemy and Jèze in the Revue de DroIT Public (1915) $153,547,700$.

17 Law of July 10, 1791, tit. I, art. 11.

18 Const. of 1848 , art. 100.

19 Art. 18.

${ }^{20} \mathrm{Law}$ of April 3, 1878, art. 1. That the exceptional law ceases automatically with the cessation of hostilities is also the opinion of the court in In re Egan, sutpra note 5.

21 Art. 7, §2. 
with which civil authorities had been invested for the maintenance of order pass to the military authorities. Nevertheless the civil authorities continue to function unless expressly suspended by the military authority." .

Article 8 gave the military tribunals jurisdiction over all persons and over all crimes and offenses, against the safety of the Republic, against the Constitution and against order and the peace.

Article 9 specifically authorized military authorities to have the right of search and seizure, the right of removing prisoners and nonresidents, of commandeering all arms and munitions, and of forbidding meetings and publications deemed to be likely to cause disorder.

Article 11 provided that constitutional guaranties not specifically suspended remained in full force and effect.

The law of 1849 was amended by a law of April 27, 1916, which specifies and limits the powers granted. It automatically ends the authority of military tribunals over civilians when peace is established, whether the state of siege is formally raised or not. If the state of siege is based on a threat of insurrection, the military tribunals have jurisdiction over civilians only in respect of the offenses specified in the Code of Military Justice or in other statutes.

Finally a law of February 19, 1917, authorizes the control over alcoholic beverages which military commanders had at various times exercised but in which they met with vigorous and sometimes successful opposition. ${ }^{22}$

The decree of 1914, together with the law that confirmed it, was the first one that extended the state of siege over the entire country. It applied to all the eighty-six departments of France, the territory of Belfort and the three departments of Algeria. It was concededly a sharp departure from the fundamental idea which in 1791 was still that which is so often mentioned in common-law discussions, the notion that martial law may not exist when the courts are still functionming. This we remember was stated in Wolf Tone's case, ${ }^{23}$ and has been frequently repeated. It may be said to be the most restrictive limit proposed to the use of martial law.

The constructive state of siege, as permitted by the Constitution of 1848 , makes no such limitation. But it is far indeed from wiping out the civil law or the civil courts. The jurisdiction of these courts is transferred to the military courts or councils who must in exercis-

22 Daxroz (1917) 4.183; cf. infra notes 38 and 39.

2327 Howell (ed.), State Trtals (1798) 613. 
ing it follow the civil law, not issue hasty judgments ad hoc. Of course the intricacies of procedure may be simplified, the times shortened and dilatory or technical pleas summarily brushed aside. But the essentials, even of procedure, may not be dispensed with, and the guaranties of civil liberty so far as they affect trials for ordinary offenses, normally punishable under the Penal Code, remain in force.

The distinction between the état de siège réel and the état de siège fictif, is extremely important and a similar distinction in the common law treatment of the situation would have clarified many situations. Much of the ardent rhetoric which has been spent in defending arbitrary and hasty acts on the part of the military authorities in time of war, would have such justification as it is entitled to, in the case of an "actual" ( $r e ́ e l)$ state of siege, that is, a situation in a city invested by the enemy or in a section actually invaded, where military engagements are in progress. Under modern conditions of allout warfare, it would apply to towns bombarded, where literally and unmistakably the current of ordinary life cannot flow at all.

Such a situation, so long as it lasts, does suspend law, as it suspends business and the ordinary relations of life. No military commandant in making decisions in such a crisis can be held to the caution and circumspection that are proper and necessary in other cases.

But the constructive state of siege, although in the French cases it implied war and invasion, also implied that the immediate and total disruption of civil life had not taken place although there was a distinct danger that it might. For that reason, this reorganization of the system of law gives an eminently satisfactory solution. It displaces civil processes only so far as they need be displaced. It expedites and simplifies procedure but it assumes the obligation to maintain law and the constitutional guaranties substantially intact.

It is a more difficult system than the cruder and more abrupt processes under martial law proper, the état de siège réel. But that it can be effective, the experience of France has shown. It takes into account actual necessities, but does not rush to an extreme that is dangerous to the bases of our state on a hurried overestimation of the urgency of the need. We might remember the words of Cromwell, who was not known for a dismclination to use drastic and sharp remedies. ". . . Necessity hath no law. Feigned necessities, imaginary necessities ... are the greatest cozenage men can put upon the Provi- 
dence of God. ..."24

If it seems absurd to suppose that in times of war military courts manned by officers can be asked to deal with the entire civil and criminal litigation of the country, two things should be borne in mind. Even under the Code of Military Justice, military courts are regularly presided over by a civil magistrate, whose civil rank depends on the military rank of the person accused. The normal court to try any military person up to and including the rank of lieutenantcolonel would be six officers ranging from brigadier general to second lieutenant, presided over by a judge of the appellate court. For officers of higher rank, the court is presided over by a presiding judge of that court. ${ }^{25}$ Similar courts may be established in war-indeed, exactly the same type of court may be and is often used.

The second fact is that judicial functions in all routine matters may be assigned to the ordinary courts which then act during the state of siege as agents of the imilitary authorities. Evidently this is what happens in the overwhelming majority of cases. The essential thing is that for adequate reasons, the military authorities may intervene and take cognizance of the cases themselves-a thing they are not likely to do, except under the pressure of actual necessity.

Beyond this jurisdiction, transferred from the civil courts, the military authorities during a state of siege have complete and independent authority over all offenses like treason, espionage, sabotage, and any other acts that hamper or interfere with the army or the war effort. In these matters the Code of Military Justice, part II, applies and departure from it can be justified only by necessity.

It will be seen that the assertion that a state of siege is legal and constitutional is amply justified. It is in no sense a dictatorship nor the rule by drum-head court martial. ${ }^{26}$ It raises, it is true, problems of a special sort.

The problem that suggests itself to common lawyers is the question of redress. Legal and constitutional as the state of siege is, the powers wielded are certainly greater and more extensive than those which military authorities normally possess. That these powers may

24 Speech to Parliament, Sept. 12, 1654, found in 4 CarLyLe, Cromwelr's Letrters AND SPEECHES (1870) 74.

25 Code de Justice Mititaire, art. 10, in Code Pénal (1938).

${ }^{26}$ In the debates on the law of 1877 , the senator Dufaure called the state of siege an "outlawry of citizens", quoting Montalivet in 1849 who called it a "dictatorship" [JouRNAL OFFrCIEL (1878) 2945]. These are rhetorical denunciations that have found no echo in legal sources in France. It is unfortunate that they have found an echo in similar sources in the United States. 
be abused-indeed, that they are highly likely to be abused-under the stress and excitement of war conditions, is beyond question. In a system that knows neither habeas corpus nor injunction nor writs or prohibition, how is such abuse prevented? ${ }^{27}$

It must be answered at once that prevention by any regular procedure is impossible. Doubtless personal representations to higher officials may check some threatened abuses, but in the main, whatever redress is available, must be obtained by enforcing civil and criminal liability against those who have been guilty of these abuses. ${ }^{23}$

If this compensatory or punitive method of redress seems poor and inadequate, it must be recalled that it is part of a system in which preventive relief is in general difficult or impossible and in which official responsibility has long been established and enforced to a . degree far beyond that known to the common law. We may well assume that much the larger number of military courts will remain within legal limits, just as we may assume it for similar officials in England and the United States. It is obvious, however, that if they go on the assumption that they are in law and in fact accountable to no one for the way in which they exercise their power, they will be less likely to impose on themselves a duty of self-restraint, than was the case in France, especially since legally enforceable official responsibility is very imperfectly developed at the common law.

But in France the double system of courts, the civil courts which culminate in the Court of Cassation and the administrative courts which culminate in the Council of State, has introduced an added complication. The question arises whether redress against any act that went beyond the powers of the military authorities must be sought in the administrative or in the civil courts. So far as the ordinary Code of Military Justice is concerned, recourse would normally be to the administrative court. Is it the same for the courts operating in a state of siege?

A much cited case, the "affaire Pelletier",, 20 dealt with this question. On August 8, 1870, an imperial decree declared the Department of the Oise to be in a state of siege. Some time later, when the state of siege still existed, on January 18,1873, the military commander of the Department, General de Ladmirault, seized the first number

$2 \pi$ The only attack that can be made before judgment is pronounced is to raise the question of jurisdiction.

28 The question has frequently arisen in the United States in this way. That it has not happened more frequently is due to the common practice of passing laws of amnesty.

29 Pelletier c. de Ladmirault, SIREY (1874) 2.28. 
of a periodical called Le Devoir published at Creil by the plaintiff Pelletier. The latter promptly brought an action against General de Ladmirault, the prefect of the Oise, $M$. Choppin, and the chief of police of Creil. He asked for a judgment declaring the seizure void, for restitution of the 2000 copies of the periodical and for $2000 \mathrm{fr}$. damages. The basis of his claim was the unconstitutionality of the decree of August 8,1870, because it had not been communicated to the Senate or published in the Official Bulletin.

The prefect admitted the jurisdiction of the court to render a judgment for damages if any personal fáult was charged, but challenged the jurisdiction of a civil court to determine the validity of the seizure. The Civil Tribunal of Senlis on May 7, 1873, gave judgment against him. The prefect applied to the Tribunal of Conflicts, which reversed the lower court. The rule of the separation of powers, it held, still prevented an administrative official from being sued in a civil court for administrative acts. This was in no way changed by the law of 1849 dealing with the state of siege. The seizure of the paper was an administrative act involving a matter of governmental policy, ${ }^{30}$ and the plaintiff alleges no circumstance which engaged the personal liability of the defendant. Only the administrative courts could deal with it. ${ }^{31}$

In a case very'much like this one, the Council of State accepted jurisdiction and decided on the facts that the formal invalidity of the decree had not been proven. This was in the Busy case, involving the periodical Mémorial des Vosges, seized on September 4, 1874, by the commandant of the sixth army. The objection was based on the failure to have the decree properly published. ${ }^{32}$ In two cases, one civil and one criminal, ${ }^{33}$ the Court of Cassation exammed the validity of the declaration of the state of siege and found it valid. The issue was not responsibility for an administrative act but involved the

80 ". . . une mésure préventive de haute police administrative. . . ." Ibid.

31. That it is not always easy to distinguish between the personal and the official responsibility of a public official is a familiar situation to common lawyers. It has nationally been much more fully discussed in France. Cf. 3 Dugurr, op. cit. supra note 15, \$72. Jèze wrote an important article on the subject in the Revue DU DRorr PuBLIC - (1909) 263 (not seen). A book by BonNard, La RESPONSABUITÉ DE L'ÉTAT ET DES Fonctionnatres (1914), compares the French with the English and German system.

32 STREY (1877) 2.343. Cf. also Chéron, S IREY (1876) 2.89. The Council of State in this case declared itself competent to determine whether the commandant had exceeded his powers.

33 Bouscarle, Sirey (1874) 1.281 , and 1.336 . 
validity of a judgment rendered by the military tribunals, and so raised the question of the jurisdiction of these tribunals. ${ }^{34}$

We must, accordingly, note that both systems of courts were, each in their appropriate field, empowered to examine the acts of the military tribunals during a state of siege. The latter could claim no exemption based on the extraordinary character of their powers.

That the Council of State would be inclined to give greater extension to the powers exercised by the military officials than the Court of Cassation, is not strange. On the question of regulating the sale or distribution of alcoholic beverages, a clear cut divergence became apparent. The Court of Cassation, in a series of decisions on January 13, March 16, April 12 and June 2, 1916, had to deal with a number of orders issued by the military commander of the seventh army and by the military commander of the department of Calvados. In the former case all sales of alcoholic beverages had been forbidden for the duration within the military zone under the general's command.

The Court of Cassation declared the orders void. So far as control of alcohol itself was concerned, the military courts had no greater power than the penal code permitted. Nor could part of the order be sustained under the general authority of the Law of 1849 to prohibit dangerous meetings (reunions). The casual congregation of persons in a restaurant or a cafe was not the type of meeting intended by the law to be prohibited. ${ }^{35}$ This restrictive interpretation is strongly approved both by $M$. Duguit, ${ }^{36}$ who may be taken to represent the more radical view, and by M. A. Esmein, ${ }^{3 \tau}$ whose political position is well toward the center.

But the Council of State on August 6, $1915,{ }^{38}$ dealing with the same point, came to precisely the opposite view of the extension of the term "meeting" and found that the term did include the casual gathering of persons in restaurants as well as formal and deliberate assemblies.

MM. Duguit and Esmein both specifically reject this interpreta-

34 The objection was based once more on the lack of proper publication in The Bulletin. The notices were in fact published by posters which were much more effective in fact than formal printing in The Bulletin would have been.

35 Reston c. Min. Publ., Darroz (1916) 1.129; De Juigné c. Deslandes, Surey (1917) 1.25 .

365 Dugurt, op. cit. supra note 15 , at 81 et seq.

37 Loc. cit. supra note 14.

38 Dalmatte, SIREY (1916) 3.9. 
tion. But M. Hauriou, ${ }^{39}$ one of the most distinguished of the jurists of his time, in an admirable note on the decision of the Council of State, approved of it, not however as a matter of interpretation, but as a decision that would have been justified under exceptional circumstances, as a law de police et $d$ ' urgence that would have been proper on the part of any criminal court, even if no state of siege had been. declared.

I think these cases and the discussion in French doctrinal texts makes it clear how French law approached the problem before us. The military officials were granted wide powers, but they must be reasonably exercised. It is emphatically a rule of law, not a welter of casual determinations which must neither be questioned nor criticised.

One of the questions early resolved by the French courts dealt with the time at which the state of siege went into effect. If the rules prohibiting ex post facto punishments were to be applied strictly, a real difficulty was presented. The cataclysms of war and rebellion are as a rule sudden, so far as their outbreak is concerned, but they have usually been in preparation for some time, and in many cases, when the state of siege is declared, the results of these preparatory acts are the first that must be dealt with. Can this be done without an unreasonable and unnecessary sacrifice of a vital right?

On August 3, 1914, a French corporal named Gruault was arrested on a charge of attempt at espionage. He had been called to the colors on August 1st, but the specific acts of which he was accused were committed before that date, and at any rate before the 5th. The state of siege was proclaimed on August 2nd, and took effect on the 5th. Gruault was condemned to death on August 15th. He appealed to the higher military court (Conseil de Revision) at Paris which on August 24th affirmed the sentence in part in a judgment going fully into the legal questions involved. The first question was the following..$^{40}$ Assuming that Gruault's act was espionage, it was punishable under the Penal Code only by imprisonment, in the case of a civilian. But the law of 1849 gave military courts jurisdiction over offenses committed "against the safety of the Republic", during a state of siege. The declaration did not create the state of siege, but proclaimed its existence. What created it was the invasion itself. All acts therefore that are connected with the situation

39 Ibid. $\mathrm{n}$.

40 Gruault, SIREY (1914) 2.245 . 
out of which a state of siege arose, are properly cognizable by the military courts even if committed before the declaration. Gruault was therefore properly convicted of a crime specifically within the statutory powers of the military court.

But on another point, the court was astonishingly technical. Gruault had been called to the colors on August 1st, but he was not required to report till August 4th. Consequently, said the Council of Revision, he was not a soldier till that date, and no violation of the Code of Military Justice could be charged against him. He could not therefore suffer military degradation, which in the case of a soldier would have preceded the death penalty. ${ }^{41}$ The commentator criticized this result sharply, ${ }^{42}$ which however followed previous decisions of the Court of Cassation. ${ }^{43}$

The qualified retroactivity of penalties in the state of siege had long been established by decisions of the Court of Cassation. The fullest examination of the question took place in some famous cases arising out of the Revolution of 1830 and out of the occupation of Roine by French troops in $1850 .{ }^{44}$ It is in the latter case that the phrase is used, which is frequently repeated in later discussion, that the military courts have jurisdiction over acts previous to the declaration which are connected with the facts that gave rise to the declaration. ${ }^{45}$

The cases of the Revolution of 1848 are themselves based ${ }^{40}$ on the debates in the Parliament after the Revolution of 1830, which together with the case of Geoffroy ${ }^{4 \pi}$ gave a complete presentation of the whole controversy and indicate the extent to which the prohibition of ex post facto laws is modified by the state of siege.

It seems to me that the French experience has inuch that can serve as a gnide. English precedents in this matter are admittedly of slight help. The brief sketch here given demonstrates that it is quite possible to maintain order and public safety under the stress even of foreigu war and of invasion, without abandoning all the methods

41 This was not without importance for Gruault's family.

42 STREY (1914) 2.245, n.

43 Lignier, StREY (1913) $1.63, \mathrm{n}$.

44 SIREY (1850) 1.226.

45 ". . la juridiction militaire . . . est compétente pour connaître même des faits antérieurs à la déclaration de l'état de siège, mais se rattachant aux faits qui ont motivé cette mésure." Ibid.

46 Legenissel, SIREY (1848) 1.641 ; StREY (1850) 1.564.

47 STREY (1832) 1.401. 
and ideas that we claim as the foundations of our state. The law of the state of siege-the constructive state, of course-is a law which is not assuming a disguise when it so styles itself. There is little reason for Americans to ignore the fact that such a law is feasible. ${ }^{48}$

48 Italian publicists distinguish between the stato di guerra, which corresponds to the état de siège réel and the stato d'assedio, which corresponds to the état de siège fictif. They are inclined to make a further division and ascribe to French law a stato d'assedio politico, which is not a widely used form in French law. The pre-Fascist Italian jurists can find in any state of siege only a complete suspension or abolition of the constitution. Cf. 1 Ractoppi and Bruneiti, Comatento Allo Statuto deI Regno (1909) \$\$111-114. Cf. the elaborate note of Cammeo in (1898) GIURISprudenza Itaidana 369.

In pre-Hitler Germany-naturally one does not speak of a legal system after Hitler-the questions here discussed are dealt with under the doctrine of Notstand, on which there is an extensive literature. The Weimar Constitution [R. V. (1919) art. 48, \$2] permits a suspension of the Bill of Rights [R. V. (1919) arts. 114, 115, 117, 118, 123, 124,153 ] in emergencies which may or may not be connected with war. Cf. 2 Hatscerer, Deutsches und Preussisches StaAtsrecht (2d ed. 1930) 171 et seq. 